\title{
High-frequency generator in the treatment of necrotizing fasciitis in a person with diabetes
}

\section{Gerador de alta frequência no tratamento de fasciíte necrotizante em pessoa com diabetes}

\section{Generador de alta frecuencia en el tratamiento de la fascitis necrotizante en persona con diabetes}

Uiara Aline de Oliveira Kaizer ${ }^{1,2^{*}}$, Marcelle Hauany Silva Costa ${ }^{3}$, Elaine Aparecida Rocha Domingues ${ }^{4}$, Maiume Roana Ferreira de Carvalho ${ }^{3}$

\section{ORCID IDS}

Kaizer UAO (D) https://orcid.org/0000-0002-9115-8043 Costa MHS (D) https://orcid.org/0000-0003-1280-691X Domingues EAR (D) https://orcid.org/0000-0002-7589-2344 Carvalho MRF (D) https://orcid.org/0000-0002-0324-7506
HOW TO CITE

Kaizer UAO; Costa MHS; Domingues EAR; Carvalho MRF (2019) Highfrequency generator in the treatment of necrotizing fasciitis in a person with diabetes. ESTIMA, Braz. J. Enterostomal Ther., 17: e1719. https://doi.org/10.30886/estima.v17.688_IN

\begin{abstract}
Objective: A case report on the treatment of necrotizing fasciitis with the use of high frequency (HF) generator in a person with diabetes. Methods: This is descriptive study of applied nature developed in an outpatient clinic in Minas Gerais. The patient underwent dressing sessions three times a week for high frequency application. Healing was weekly evaluated using the Pressure Ulcer Scale Healing (PUSH) instrument and Image J software. Results: The area was significantly reduced, which was measured during six weekly evaluations. In the first four evaluations, a progressive reduction of the lesion was obtained in $11.78 \mathrm{~cm}^{2}$, that is, $90 \%$ of the area. Conclusion: The use of the AF generator was effective in the treatment of necrotizing fasciitis, reducing the lesion area.
\end{abstract}

DESCRIPTORS: Diabetes mellitus. Nursing care. Nursing evaluation. Healing. Stomatherapy.

\footnotetext{
1.Prefeitura de Sorocaba - Sorocaba/SP - Brazil

2.Universidade Estadual de Campinas - Programa de Pós-Graduação da Enfermagem - Campinas/SP - Brazil

3.Universidade Vale do Rio Verde - Curso de Enfermagem - Três Corações/MG - Brazil

4.Universidade Estadual de Campinas - Campinas/SP - Brazil

Correspondence author: uiara_oliveira@hotmail.com

Received: Jan. 22, 2019 | Accepted: Aug. 28, 2019
} 


\section{RESUMO}

Objetivo: Relato de caso sobre o tratamento da fasciíte necrotizante com a utilização do gerador de alta frequência (AF) em uma pessoa com diabetes. Métodos: Trata-se de um estudo descritivo de natureza aplicada, desenvolvido em um ambulatório no interior de Minas Gerais. A paciente foi submetida a sessões de curativo durante três vezes na semana para aplicação de alta frequência. A cicatrização foi avaliada semanalmente por meio do instrumento Pressure Ulcer Scale Healing (PUSH) e pelo software Image J. Resultados: Houve redução significativa da área da lesão, que foi mensurada durante seis avaliações semanais. Nas quatro primeiras avaliações, foi obtida redução progressiva da lesão em 11,78 cm², ou seja, $90 \%$ da área. Conclusão: O uso do gerador de AF foi efetivo no tratamento da fasciíte necrotizante, com redução da área da lesão.

DESCRITORES: Diabetes mellitus. Cuidados de Enfermagem. Avaliação em Enfermagem. Cicatrização. Estomaterapia.

\section{RESUMEN}

Objetivo: Relato de caso sobre el tratamiento de la fasciitis necrotizante con la utilización del generador de alta frecuencia (AF) en una persona com diabetes. Métodos: Se trata de un estudio descriptivo de naturaleza aplicada, desarrollado en un ambulatorio en el interior de Minas Gerais. La paciente fue sometida a sesiones de curativo durante tres veces a la semana para aplicación de alta frecuencia. La cicatrización fue evaluada semanalmente a través del instrumento Pressure Ulcer Scale Healing (PUSH) y área de la lesión por el software Image J. Resultados: Hubo una reducción significativa en el área de la lesión, que se midió durante seis evaluaciones semanales. Durante las cuatro primeras evaluaciones se obtuvo una reducción progresiva de la lesión en 11,78cm², es decir, el $90 \%$ del área. Conclusión: El uso del generador de AF fue efectivo en el tratamiento de la fascitis necrotizante, con reducción del área de la lesión.

DESCRIPTORES: Diabetes mellitus. Cuidados de enfermería. Evaluación en enfermería. Cicatrización. Estomatoterapia.

\section{INTRODUCTION}

Diabetes mellitus is one of the major chronic diseases affecting the world's population and is becoming a public health problem. In Brazil, estimates verified that 11.9 million individuals, between 20 and 79 years old, have diabetes, classifying the country as the fourth in the world ranking of diabetes mellitus ${ }^{1}$. Several complications are resulting from the disease, which includes macrovascular, microvascular complications, neuropathies, and greater susceptibility to infections ${ }^{2}$.

Necrotizing fasciitis is a rare and severe infection characterized by extensive and rapidly progressive necrosis. It was described in 1871 by surgeon Dr. Joseph Jones, however, the term necrotizing fasciitis began to be used by Wilson Ben in 1952, to describe its main characteristic: necrosis of the subcutaneous cellular tissue maintaining the underlying muscle preserved. Its incidence is higher in adults with predisposing risk factors, such as type 2 diabetes, advanced age, cancer, peripheral vascular disease, and those affected by open and closed trauma. It is characterized by extensive necrosis that can affect the superficial fascia of soft tissues, the abdominal wall, limbs, and perineum, by venous thrombosis of small vessels and suppuration. Its treatment should be early, through the use of broad-spectrum antibiotics, aggressive surgical debridement, and clinical and nutritional support measures ${ }^{2}$.

The practice of wound care is a nursing specialty recognized by the Brazilian Society of Nursing in Dermatology (Sobende) and by the Brazilian Association of Enterostomal Therapy (Sobest) ${ }^{3,4}$. This practice is a responsibility assigned to the nurse who must assess the injury and prescribe appropriate treatment. Associated to this fact, the Brazilian Federal Law No. 7.498 of June 25,1986 ${ }^{5}$, the Federal Decree No. 94.406 of June $08,1987^{6}$ and the Resolution of the Federal Council of Nursing (Cofen) No.358 of October 15, $2009^{7}$ state on the Systematization of Nursing Assistance (SNA); Cofen Resolution No. 567/2018 regulates the role of the nursing staff in the care of patients with wounds, with autonomy to participate in the evaluation, development of protocols, selection and indication of new technologies in the prevention and treatment of injuries ${ }^{8}$.

Thus, the nursing professional is responsible for planning the care of the person with wound, through therapeutic methods, and with the interdisciplinary staff; the nurse aims to help in the healing of the wound without complications, with the restoration of functions in the shortest possible time and with the prevention of sequelae 9

Among the use of new technologies in the treatment of injuries, the use of electrical stimulation stands out. Studies indicate that electrical stimulation is an excellent option 
to help improve the healing process by promoting the migration of epithelial cells, macrophages, and neutrophils to the lesion. Also, electrical stimulation alters DNA and results in the greater synthesis of collagen by fibroblasts enhancing wound healing ${ }^{10}$.

The high-frequency (HF) generator is a device that operates with alternating electric currents of high and low intensities, with an approximate voltage of 30 to 40 thousand volts and a frequency of 150 to $200 \mathrm{kHz}$. It has glass electrodes that contain rarefied air (vacuum) or gas (neon, xenon or argon) in its interior. The passage of electric current through the equipment triggers the ionization of gas molecules that become fluorescent due to the large energy impact. When in contact with the electrode, the skin promotes a sparkle that transforms oxygen into ozone ${ }^{11}$.

Ozone was discovered in 1834 by Christian Friedrich Schönbein, who described it as an oxidizing and disinfecting substance. In 1857, the chemist Werner Von Siemens developed the HF generator, a device that forms ozone gas by electric discharges into oxygen atoms. The treatment with ozone was introduced in Brazil in 1975, by doctor Heinz Konrad ${ }^{11}$.

Ozone is a powerful oxidant with antimicrobial and fungicidal effects that, when in contact with organic fluids, forms reactive oxygen molecules, which in turn provide benefits to tissue repair through biochemical events of cellular metabolism ${ }^{11}$.

Ozone therapy is a technique that uses ozone as a therapeutic agent. In the treatment of chronic wounds, its use stimulates the granulation tissue formation and neoangiogenesis ${ }^{11}$.

The HF generator is capable of producing physiological effects, such as peripheral vasodilation, increased blood flow, and consequently greater demand for oxygenation and cellular metabolism, favoring the healing process. This happens due to the thermal effects that are produced by an electric current that traverses the organism, creating the ozone effect by the electric spark that crosses the electrode, eliminating the pathogens and oxygen, responsible for the fibroplasia for intercellular matrix preparation ${ }^{10}$.

Recommendations for the therapeutic use of the highfrequency generator and ozone therapy are diverse, and there is evidence proving its efficacy. Its advantages include powerful antimicrobial action, easy application, low cost, and no adverse effects. Its clinical results make the highfrequency device an ally for the treatment of injuries ${ }^{10}$.
However, despite all the beneficial effects that qualify the high-frequency generator as a viable tool for treating injuries, there is a shortage of scientific studies on its use.

Considering these facts, this study aimed to report the effects on the healing process in the treatment of necrotizing fasciitis, using the $\mathrm{HF}$ generator in a person with diabetes.

\section{METHODS}

This is a descriptive study, case report type, developed in an outpatient wound care clinic in the state of Minas Gerais, from August to October 2018. It was performed on a 52-year-old woman with type 2 diabetes mellitus and diagnosis of necrotizing fasciitis.

To evaluate the evolution of the wound, measurements were taken using a 12 -megapixel camera with $f / 2.2$ aperture, digital zoom up to 5 times and true tone flash. Image analysis was performed using the ImageJ software. The wound was evaluated at the beginning of treatment and reassessed weekly after that. The evaluation of the wound healing process was performed using the Pressure Ulcer Scale Healing (PUSH) Tool.

Adapted and validated in Brazil by Santos and Carvalho ${ }^{12}$, PUSH is an instrument used to evaluate wound healing in pressure lesions because it describes the conditions and evolution of injuries, where it evaluates the wound area, amount of exudate present in the wound and wound bed appearance.

The "wound area" item is measured in square centimeters and relates the greatest length (in the cephalocaudal direction) to the greatest width (in a horizontal line from right to left). The scores range from 0 to 10 , and the values range from 0 to $>24 \mathrm{~cm}^{2}$, according to the area obtained ${ }^{12}$.

The "amount of exudate present in the wound" item is evaluated after removal of the dirty coverage and before topical dressing application. It is classified as absent, small, moderate and large with scores ranging from 0 (absent) to 3 (large) ${ }^{12}$.

The "wound bed appearance" item represents the type of tissue present in the wound during the evaluation and is divided into: necrotic tissue (bedsores, black color), devitalized tissue (mucoid yellow); granulation tissue (pink or red 
color); epithelial tissue (pink or bright) and healed tissue (closed wound). The scores in these tissues are classified as 0 (closed injury), 1 (epithelial tissue), 2 (granulation tissue), 3 (slough), and 4 (necrotic tissue) ${ }^{12}$.

When the subscores of the items are totaled, a possible variation of 0 to 17 is obtained, and the higher scores indicate worse wound conditions ${ }^{12}$.

In the first consultation, the patient's history was collected to start the treatment of the wound, and she was invited to participate in the study. During the following discussions, the patient was referred to the dressing room. Wound cleaning was performed with irrigation of $0.9 \%$ lukewarm saline solution and, after that, the application of the HF generator was performed three times a week with a duration of $1 \mathrm{~min}$ at the margins and in the bed, superimposed on sterile gauze.

As primary coverage, $2 \%$ papain gel and essential fatty acids were applied to the perilesional region of the wound, and the lesion was occluded with sterile gauze and fixation with micropore.

The data collection instrument was: characterization form for evaluation with sociodemographic and clinical data, comorbidity, and data related to the evaluation and classification of the lesion's characteristics. The evaluation of the injury was performed based on the aspects of the wounds that comprise three dimensions: type of tissue, amount of exudate, and area of the lesion. Subsequently, the researcher performed the perimetry of the wound area with a ruler, captured the images, and performed the treatment with $\mathrm{HF}$.

The HF generator used in the study was an Ibramed $\AA$ portable device, dual voltage 110/240 V, 50 and $60 \mathrm{~Hz}$, with dimensions of $7 \mathrm{~cm}$ wide, $11 \mathrm{~cm}$ deep and $6 \mathrm{~cm}$ high, and approximately $500 \mathrm{~g}$ in weight.

A medium intensity electrical sparking technique was used with a greater spherical electrode. It is noteworthy that the material that came into contact with the wound was sanitized and disinfected with $70 \%$ hydrated ethylic alcohol.

The research project was submitted to the Ethics Committee and approved under report 2,833,544, as recommended by Resolution No. 466 of December 12, 2012, from the National Health Council (NHC), and the invited patient signed the free and informed consent form (ICF).

\section{RESULTS}

C.H.S.R, 52 years old, resident of Três Corações/MG, hypertensive, diabetic, smoker. In July 2018, after a waxing session, she presented a pustule in the right infragluteal region. She sought outpatient care with an infectious disease specialist who indicated antibiotic therapy for one month. After this period, the patient had no improvement in her clinical condition, with gradual worsening of the pustule, with rupture and the presence of local hyperemia, pain, flaking skin, and a foul odor. She was referred by the infectious disease specialist for a hospital stay, being diagnosed by the local surgeon with necrotizing fasciitis and referred to surgical debridement. After the period of 11 days of hospital stay, the outpatient treatment of the lesion was started.

At the initial evaluation, the wound presented an area of $13.09 \mathrm{~cm}^{2}$, resected perilesional region, detached and irregular margin, about $70 \%$ of granulation tissue, $10 \%$ of slough and $20 \%$ of subcutaneous tissue exposure (shown in Fig. 1), moderate amount of exudate in serous, yellowish and odorless color.

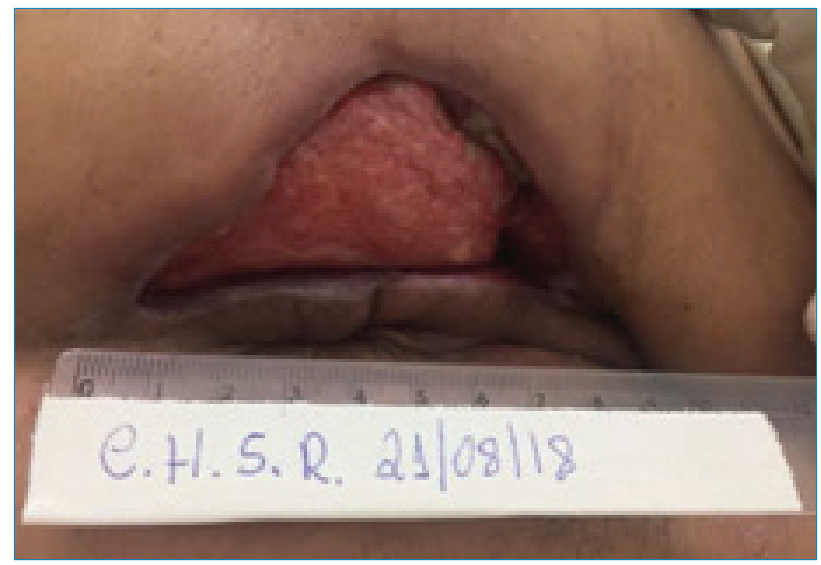

Figure 1. Lesion after the first application.

After seven applications, the lesion presented an area of $4.58 \mathrm{~cm}^{2}$, intact perilesional region, irregular and detached margin, 95\% granulation tissue and 5\% exposure of subcutaneous tissue, a moderate amount of exudate with serous appearance, odorless and yellowish in color, as shown in Fig. 2.

After 15 applications, the lesion presented an area of $1.94 \mathrm{~cm}^{2}, 95 \%$ granulation tissue, a small amount of exudate in serious aspect, odorless and yellowish in color. Concerning the area of the lesion, the patient presented a significant improvement in the healing process, measured using Image J software, from 13.09 to $1.94 \mathrm{~cm}^{2}$, as shown in Fig. 3 . 


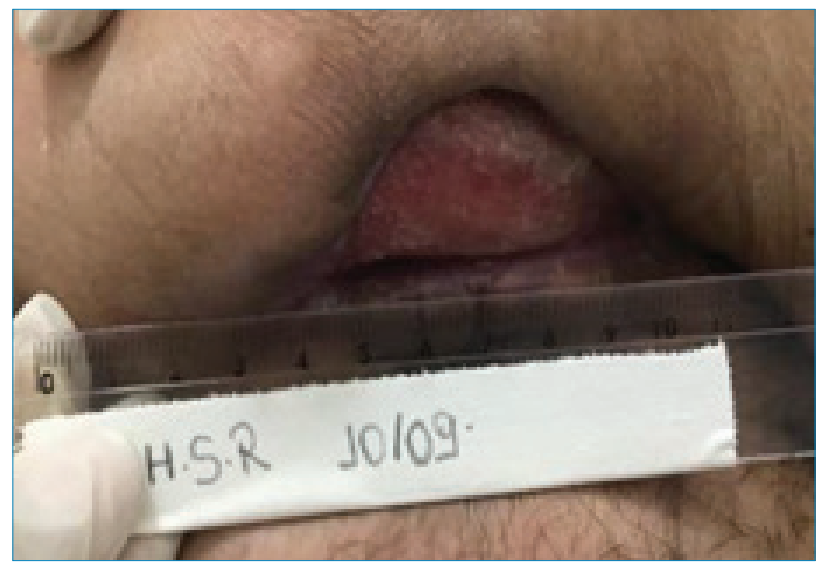

Figure 2. Lesion after seven applications.

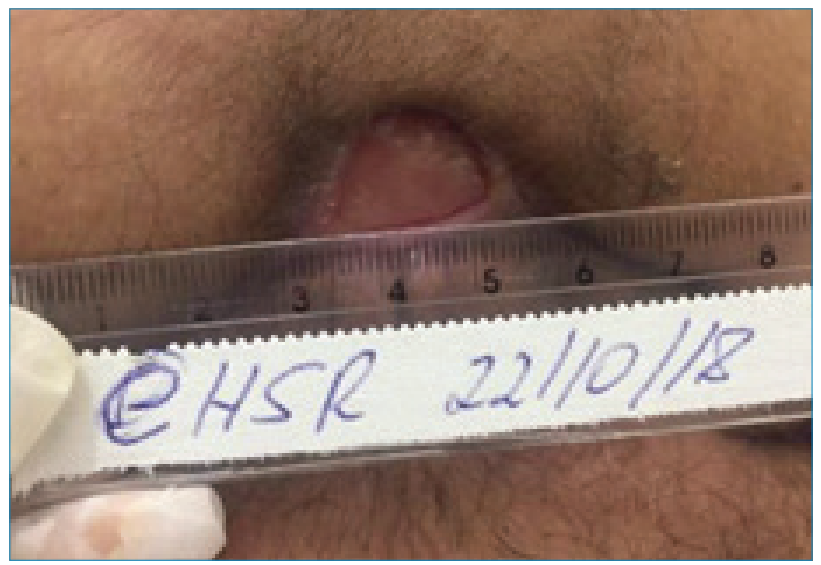

Figure 3. Lesion after 15 applications.

In the graphic below (Fig. 4), the values of the PUSH scale used to measure the area in square centimeters, the quantity of exudate and type of tissue present in the lesion, are represented.

It can be evidenced that there was a significant improvement of the lesion during the six weeks of evaluation. In the initial assessment, a PUSH score of 13 was obtained, since the wound presented an area of $13.09 \mathrm{~cm}^{2}$, a moderate amount of exudate and granulation tissue in greater evidence. In the three subsequent evaluations, a noticeable improvement of the lesion was observed, evidenced in the reduction of its area, which presented PUSH score 7 in the fourth evaluation, with an area of $1.31 \mathrm{~cm}^{2}$, a limited amount of exudate and evident granulation tissue. In the sixth and last evaluation, PUSH score 7 was obtained, the lesion area was $1.94 \mathrm{~cm}^{2}$ with a limited amount of exudate and evident granulation tissue.

In the graphic below (Fig. 5), the area of the lesion evaluated through the ImageJ software is presented. During the first four evaluations, a progressive reduction of the injury was obtained in $11.78 \mathrm{~cm}^{2}$, that is, $90 \%$ of the area. Considering the first and last evaluations, a decrease of
$85.17 \%$ of the lesion area was obtained. It is noteworthy that the lack of periodicity of the patient in the final two weeks of treatment may be indicative for the increase in the area of the lesion since there was an increase of $0.22 \mathrm{~cm}^{2}$ in the area.

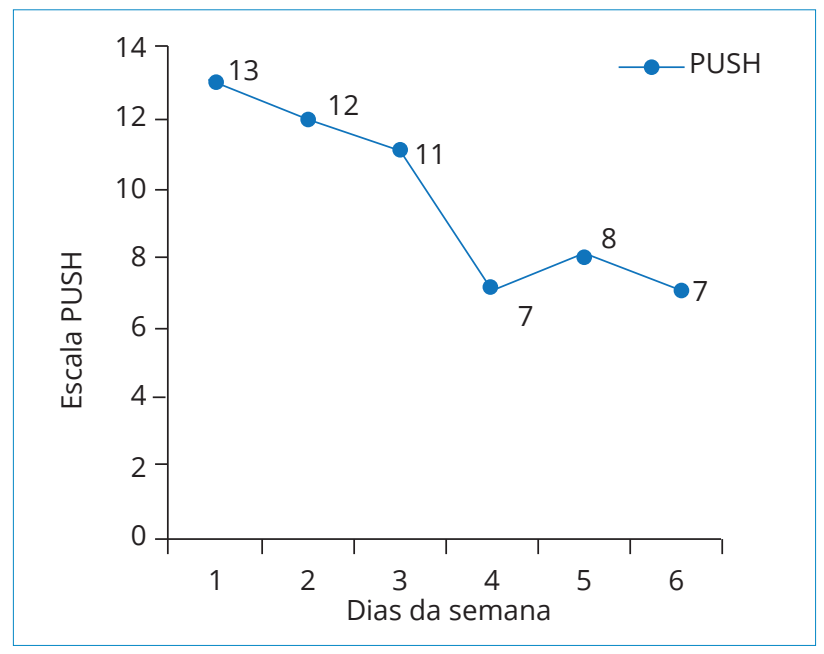

Figure 4. PUSH scale.

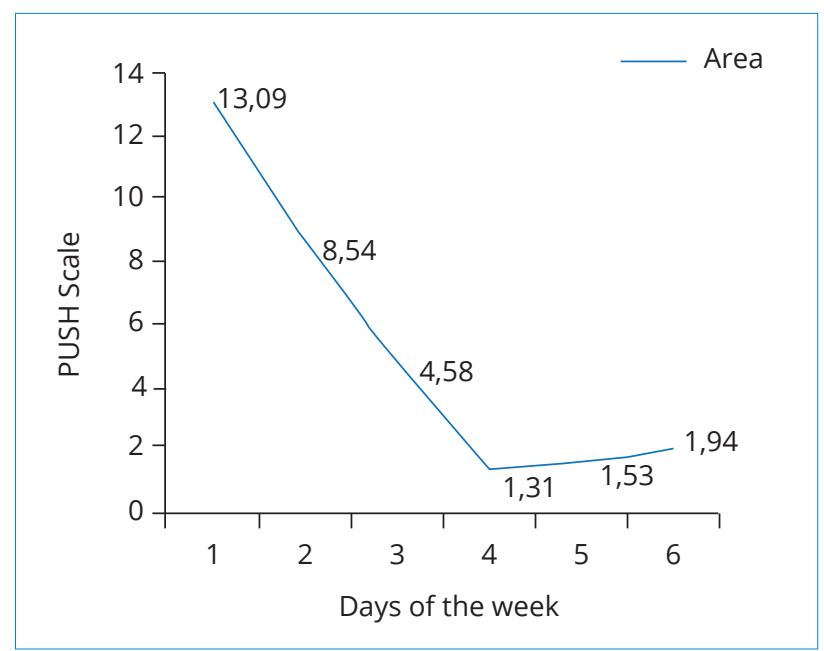

Figure 5. The area of the lesion during treatment.

\section{DISCUSSION}

This study aimed to describe the use of $\mathrm{HF}$ generator in the treatment of a necrotizing fasciitis wound in a patient with type 2 diabetes mellitus, with a progressive and significant reduction of the lesion after the first four evaluations, with almost $90 \%$ of the area healed.

Another study also reported the effectiveness of the use of HF generator with ozone as a therapeutic resource in the treatment of wounds, in which it obtained stimulation of the healing process and total healing (62.2\%), followed by improvement of the wounded aspect $(43.5 \%)$ and pain reduction $(17.4 \%)^{11}$. 
The electrical stimulation by HF promotes wound healing because its thermal effect provides peripheral vasodilation, increases cell oxygenation, encourages the migration of epithelial cells, macrophages, and neutrophils, and stimulates fibroblasts to produce collagen ${ }^{11}$.

Experimental studies with rats show in their results that electrical stimulation improves wound healing by stimulating growth factors in the dermis and epidermis ${ }^{13}$. A study in humans indicated that electrical stimulation could be an effective intervention in the treatment of various pathological conditions. Descriptive research conducted with three older people with pressure lesion showed that electrical stimulation reduced in $64.5 \%$ the area of the injury of one individual, and there was complete healing of the pressure lesion in the other two patientst $3 />14$. The electrical stimulation in people with diabetes, applied during 12 weeks, led to complete healing of the lesions ${ }^{15}$.

Two other studies with the use of HF generator for the treatment of pressure lesion were also adequate. In the first, after five weeks of treatment with the application of $\mathrm{HF}$ three times a day for $15 \mathrm{~min}$, using the sparking technique, there was a reduction in the size of the lesion ${ }^{11}$. In the second study, the electrical sparking technique was also used, with an amplitude of $80 \%$ of the apparatus during 1 min per $\mathrm{cm}^{2}$ of the lesion with an improvement in healing and a decrease in its area ${ }^{10}$.

There is unanimity among several authors regarding the use of ozone, whether applied through ozonized sunflower oil or diluted in water, since ozone provides antimicrobial, bactericidal and fungicidal effects, in addition to its effectiveness in tissue repair. In the treatment of chronic wounds, the use of ozone-induced the granulation tissue formation due to its antiseptic effects ${ }^{11}$.

Chronic wounds have an impact on the burden on the Brazilian Unified Health System (SUS, acronym in Portuguese for Sistema Único de Saúde) and this issue has become widely discussed in health economic forums due to the exacerbated use of material resources and low resolution of the problem. Therefore, the use of technological resources in a systematic way is crucial to provide a cure for patients ${ }^{10}$.

Nursing is a science that promotes prevention and rehabilitation through care. Thus, professionals should use existing technologies and resources to provide a good quality of care. Technologies have been used in the health area in educational and healthcare contexts as a complementary way of teaching methodologies ${ }^{10}$.

It is essential to develop studies and technological processes of practical application, to ensure that the nurse can always be updated. Technology, when used in daily nursing, brings possibilities to improve the care provided, principally to the person with wound ${ }^{16}$.

\section{CONCLUSION}

The use of HF generator was valid based on the result obtained, i.e., with significant reduction of the area of the lesion, however, it is necessary that the findings evidenced in this study may be used to discuss and make feasible preventive and treatment measures and that new research related to the subject may be encouraged, with a more significant number of people, including other methodological approaches.

\section{AUTHOR'S CONTRIBUTION}

Conceptualization, Domingues EAR and Costa MHS; Methodology: Domingues EAR and Costa MHS; Writing - Original Draft, Domingues, EAR, Costa MHS, Carvalho MRR, and Kaizer UAO; Writing - Review and Editing, Domingues EAR, Carvalho MRR and Kaizer UAO; Supervision, Domingues EAR.

\section{REFERENCES}

1. Klafke A, Duncan BB, Rosa RS, de Moura L Malta DC, Schmid MI. Mortalidade por complicações agudas do diabetes melito no Brasil, 2006-2010. Epidemiol Serv Saúde. 2014;23(3):45562. https://doi.org/10.5123/S1679-49742014000300008

2. Soares FG, Pessanha ALP, Lemos LVB. Fasciíte Necrotizante em paciente diabético. Rev Cient Fac Med Campos. 2013;8(1):28-31.
3. Conselho Federal de Enfermagem. Resolução COFEN No 570 de 09 de março de 2018 [Internet]. [cited 13 sept 2019]. Available at: http://www.cofen.gov.br/resolucao-cofenno-0570-2018_61172.html

4. Yamada BFA, Ferrola EC, Azevedo GR, Blanes L, Rogenski NMB, Santos VLCG. Competências do Enfermeiro Estomaterapeuta 
(ET) ou do Enfermeiro Pós-graduado em Estomaterapia (PGET). Estima, Braz J Enterostomal Ther. 2008;6(1).

5. Brasil. Lei nº 7.498 de 25 de junho de 1986. Que dispõe sobre o Exercício profissional da Enfermagem, e dá outras providências. [cited 13 sept 2019]. Available at: http://www. cofen.gov.br/lei-n-749886-de-25-de-junho-de-1986_4161. html

6. BRASIL. Decreto n 94.406 de 08 de junho de 1987. Que regulamenta a Lei $n^{\circ} 7.498$ de 25 de junho de 1986, que dispõe sobre o Exercício profissional da Enfermagem, e dá outras providências. COFEN. [cited 13 sept 2019]. Available at: http://www.cofen.gov.br/decreto-n-9440687_4173.html

7. Conselho Federal de Enfermagem. Resolução COFEN No 358 de 15 de janeiro de 2009 [Internet]. [cited 13 sept 2019]. Available at: http://www.cofen.gov.br/resoluocofen-3582009_4384.html

8. Conselho Federal de Enfermagem (Brasil). Resolução COFEN nº 567 de 29 de janeiro de 2018. [Internet]. [cited 03 mar 2018]. Available at: http://www.cofen.gov.br/ resolucao-cofen-no-567-2018_60340.html

9. Morais GFC, Oliveira SHS, Soares MJGO. Avaliação de feridas pelos enfermeiros de instituições hospitalares da rede pública. Texto Contexto - Enferm. 2008;17(1):98-105. https://doi.org/10.1590/S0104-07072008000100011

10. Korelo RIG, Oliveira JנJ, Souza RCA, Hullek RF, Fernandes LC. Gerador de alta frequência como recurso para tratamento de úlceras por pressão: estudo piloto. Fisioter
Mov. 2013;26(4):715-24. https://doi.org/10.1590/S010351502013000400002

11. Oliveira LMN. Utilização do ozônio através do aparelho de alta frequência no tratamento da úlcera por pressão. Rev Bras Ciên Saúde. 2011;9(30):41-6. https://doi.org/10.13037/ rbcs.vol9n30.1418

12. Santos VLCG, Carvalho VF. Reapresentando o instrumento pressure ulcer scale for healing (PUSH) para avaliação de úlceras por pressão e úlceras crônicas de perna. Estima, Braz J Enterostomal Ther. 2009;2(2).

13. Kutlu AK, Çeçen D, Gürgen SG, Sayin O, Çetin FA. Comparison study of growth factor expression following treatment with transcutaneous electrical nerve stimulation, saline solution, povidone-iodine, and lavender oil in wounds healing. Evid Based Complement Alternat Med. 2013;(1):1-9. https://doi. org/10.1155/2013/361832

14. Almeida R, Giacomolli CMH, Coelho EL, Bittencourt VL, Callegaro CC, Stumm EMF. Gerador de alta frequência no tratamento de lesão por pressão em idosos. Rev Enferm UFPE On Line. 2017;11(8):3136-142.

15. Barnes R, Shahin Y, Gohil R, Chetter I. Electrical stimulation vs. standard care for chronic ulcer healing: a systematic review and meta-analysis of randomised controlled trials. Eur J Clin Invest. 2014;44(4):429-40. https://doi. org/10.1111/eci.12244

16. Queiroz PES, Schulz RS, Barbosa JDV. Importância da tecnologia no processo de enfermagem para o tratamento de feridas crônicas. Rev Enferm Contemp. 2017;6(2):158-166. 